\title{
“Tasarı Geometri - Teknik Resim" ve "Perspektif” Derslerinin, Mimarlık Eğitimi Düşünsel Altyapısına Etkisi ve Prof. Dr. Yılmaz MORÇÖL
}

\author{
Didem ERTEN BILGGiç ${ }^{1 *}$, Nihan KONAK ${ }^{2}$
}

\section{öz}

Mimarlık, Planlama ve Tasarım Temel Alanı eğitiminde özellikle ilk yıl için ana başlık ollan "tasarım eğitimi"; üç boyutlu düşünmeyi, kurgulamayı ve bunu mimari iletişim dili olan tasarı geometri-teknik resim, perspektif aracılığı ile iki ve üç boyutlu olarak görselleştirmeyi hedefler. Tasarım atölyeleri ve öğrenciöğretim elemanı arasındaki sıkı iletişim bu hedefe ulaşmada etkin parametrelerdir. Tasarım dünyasının ortak iletişim dili olan tasarı geometri-teknik resim, perspektif konuları geçmişten günümüze tasarımların kâğıda aktarılmasında ve tasarımın tashih edilerek geliştirilmesinde etkili olmuştur.

Bu çalışmada, "tasarı geometri-teknik resim", "perspektif” konularının günümüze gelinceye kadar yaşamda ne şekilde yer bulduğu, Mimarlık, Planlama ve Tasarım Temel Alanı eğitimindeki etkin rolü ve eğitimci olarak bu dersleri vererek kuşakları yetiştirmiş olan Prof. Dr. Yılmaz MORÇÖL'ün mesleki ve akademik yaşama katkıları anlatılmaktadır.

Anahtar Kelimeler: Tasarı-geometri, teknik resim, perspektif, mimarlık eğitimi

\section{The Effect of "Descriptive Geometry" "Technical Drawing" and "Perspective" Lessons to the Architectural Education's Intellectual Infrastructure and Prof. Dr. Yılmaz MORÇÖL}

\begin{abstract}
Architecture, Planning and Design Education, which constitutes the main topic in the primary field of architecture education especially during the first year, is aimed for three-dimensional thinking, design and the visualization of this in two and three dimensions through the architectural communication language of descriptive geometry-technical drawing, perspective. The design workshops and the close studentacademician communication are effective factors in achieving this goal. The topics of descriptive geometry-technical drawing and perspective, which are the common communication language of the design world, have been effective throughout history in transferring the made designs onto paper and the correction and development of these designs.

This paper discusses the way that the topics of descriptive geometry-technical drawing and perspective take place in history, their effective roles in the primary field of Architecture, Planning and Design Education and the contributions of Prof. Dr. Yılmaz MORÇÖL, who has raised generations by teaching these courses, to the professional and academic life.
\end{abstract}

Key words: Descriptive geometry, technical drawing, perspective, architecture education.

\footnotetext{
${ }^{1}$ Yrd. Doç. Dr., Kocaeli Üniversitesi, Mimarlık ve Tasarım Fakültesi, İç Mimarlık Bölümü, didemerten@gmail.com

${ }^{2}$ İç Mimar, Kocaeli Üniversitesi, Sosyal Bilimler Enstitüsü, Yüksek Lisans Öğrencisi *ilgili yazar / Corresponding author: Didem ERTEN BíLGiç, didemerten@gmail.com Gönderim Tarihi: 24.10 .2016

Kabul Tarihi: 29.11.2016
} 


\section{GíRiş}

Mimarlık, Planlama ve Tasarım Temel Alanında ${ }^{3}$ eğitim; "kişi", "süreç" ve "ürün" olmak üzere üç temel olguya dayanır ve öncelikle "tasarım yapma" üzerine yoğunlaşır. Tasarım, "analiz" ile başlayıp, "değerlendirme" ile son bulan eylemler bütünüdür. Tasarlama eylemi; bilgi, yorum ve ifade aşamalarından oluşmakta olup, bu süreçler arasındaki ilişkilerin dinamiği ile çok boyutlu bir yapı kazanır. (Goldschmidt,1991)

Mimarlık, Planlama ve Tasarım Temel Alanı eğitimi sürecinde tasarım eylemi gerçekleştirilirken; stüdyo/atölye, proje yürütücüsü/tasarım eğitmeni, öğrenci/tasarımcı adayı olarak üç temel bileşenden söz edilebilir. Bu temel alanı eğitimi; yalnızca tasarlama eyleminden değil, tasarlama eylemi ile birlikte onu destekleyen bileşenlerden, yani teorik derslerden oluşmaktadır. Mimarlık, Planlama ve Tasarım Temel Alanı eğitiminde amaç; sorgulayan, üç boyutlu düşünebilen ve algılayabilen, eleştirel düşünme becerisine sahip, ürettiği düşünceyi somut hale getirebilen bireyler yetiştirmektir. Bu bağlamda öğrencilerden beklenen; yeni, özgün, farklı, yaratıcı bir ürün ortaya koymasıdır. Alan kapsamındaki "Mimarlık", "İç Mimarlık", "Şehir Bölge Planlama", "Endüstri Ürünleri Tasarımı" ve "Peyzaj Mimarlığı" bölümlerinde tasarım eğitiminin başlangıcı, öğrenci için bir paradoks durumunda olup, özellikle ilk yıl neyin öğrenilmesi gerektiğini bilinememekte, öğrenci bildiğini ve keşfettiğini çizememekte, çizdiğini de ders yürütücüsüne anlatmakta zorlanmaktadır.

Eğitim süreci içinde zamanla; sorgulama, akıl yürütme, bilgiyi düzenleme ve dönüştürme becerilerini kazanarak bu açmazdan kurtulmaya başlamaktadır. Diğer alanlardan farklı olarak bu alanın eğitimi; sadece öğrenme-öğretme eğitimini değil, farklı zihinsel aşamaları da içerir. Öğrenci; sezerek, deneyerek, düşünerek ve en önemlisi çizim yaparak öğrenir. Eğitim sadece proje yürütücüsü ile öğrenci arasında gerçekleşmez. Diğer tüm öğrencilerin katıldığı, sosyal bir etkileşim olarak gerçekleşir. Bu esnada iletişim aracı, sadece sözel ve sayısal simgeler ile sınırlı kalmaz. Diyagram, eskiz çalışması, üç boyutlu model gibi araçların da katıldığı bir hal alır. Dışarıdan bakıldığında, karmaşık ve zorlu bir süreç gibi algılanan bu durumu aslında tek dile indirgeyen ve karmaşayı ortadan kaldıran, çizim kuralları bütünü ve üç boyutlu tasarlayabilme yetisidir.

Eğitim süreci sonrasında; ne kadar yenilikçi ve başarılı bir tasarım ortaya konsa da onu herkesin ortak kullandığı bir dille anlatabilmek önem taşımaktadır. Adı geçen bölümlerde bu dil, çizim yoluyla gelişmiştir. Mimarlık, Planlama ve Tasarım Temel Alanı eğitiminde çizim dilini geliştiren en önemli dersler ise, "Tasarı Geometri ve Teknik Resim" ile "Perspektif" dersleridir. Bu makale ile son yıllarda mimarlık temel alanı eğitiminde "Eğitimde Yeniden Yapılanma" başlığı altında yapılan çalışmalar ile adı geçen derslerin müfredat içindeki ağırlığının azaltılması nedeniyle, söz konusu derslerin önemine yeniden dikkat çekmek amaçlanmaktadır.

Bu derslerin mimarlık temel alanı eğitimindeki önemini ele alırken, "Tasarı Geometrinin Son Duayeni" tanımlanan, mimar kimliğinden çok eğitimci kişiliği ile ön plana çıkan "Perspektif" ve "Perspektifte Deformasyon" gibi önemli konularda çalışmış, Kocaeli Üniversitesi Güzel Sanatlar Fakültesi İç Mimarlık Bölümü kurucusu Prof. Dr. Yılmaz MORÇÖL'den bahsedilecektir.

\footnotetext{
${ }^{3}$ URL1:http://www.yok.gov.tr/documents/10279/314121/A tablo8 300114.pdf/93603193-5de3-4ff9-928e245cc184b2b1, izlenme tarihi: 29112016
} 


\section{TASARI GEOMETRI VE TEKNIK RESIM}

Mimarlık, Planlama ve Tasarım Temel Alanında eğitim alan bir öğrencinin, anlatım dili yani tasarladığı ürünü ifade etme aracı çizimdir. Bir bina, mekân, mobilya, endüstriyel ürün veya herhangi başka bir obje tasarlarken öncelikli olarak kullanılması serbest veya kurallı el çizimidir. Çünkü tasarım sürecine başladığında çok hızlı çalışan beynin çalışma hızına en yakın olan hız, el çizimi ve eskizler ile yakalanmaktadır. Düşünme hızına yetişemeyen el çizimi de anlık olarak beliren düşüncelerin kâğıda aktarılmasına yeterli olamaz. El çizimi ile düşüncelerin kâğıda aktarılabilme yeterliği, tasarı geometriteknik resim ve perspektif dersleriyle kazanılabilmektedir.

Teknik resim; belirli çizim teknikleri çerçevesinde özel çizgiler, işaretler ve semboller kullanılarak oluşturulmuş bir dil olup mimar, mühendis ve diğer teknik elemanlar arasındaki ortak dili sağlar. Dünyanın farklı yerlerindeki tüm teknik unvan sahibi meslek insanlarının fikirlerini birbirlerine aktarabildikleri bir oluşumdur ve teknik resim; bir tasarımın başlangıcından, son halini alıncaya kadarki sürecin tümünde kullanııı.

Tasarı geometri ise; uzayda tasavvur edilmiş cisimleri, izdüşümleriyle birlikte gösteren geometridir. Antik Çağ Dönemi geometrisinin önemli ismi olan ve "Konikler" adlı eseri ile daire, elips, hiperbol ve parabolü tanımlayan Pergeli Apollonios'tan sonra Rönesans'a kadar kayda değer bir gelişme yaşanmamıştır. Rönesans Dönemi'nin en önemli sanatçılarından olan Leonardo da Vinci'nin yaptığı tasarımlara ait çizimler, herhangi bir çizim kuralı ortaya koymasa da teknik resim açısından ilk sayılabilir. Sonrasında tasarı geometrinin kurulup sistemleştirilmesi ise Fransız Matematikçi Gaspard Monge tarafından gerçekleştirilmiştir. Matematik tarihi eserlerinde kendisinden "tasarı-geometriyi kurmuş ve sistemleştirmiştir" şeklinde bahsedilmektedir. Gaspard Monge $^{4}$ (1746- 1818) tasarı geometrinin konusunu ve amacını "sadece iki boyutlu olan bir resim kâğıdı üzerine üç boyutlu ve tam doğru olarak, tabiatta belli cisimleri temsil etme ve eksiksiz bir tanım ile tasvir yapmak suretiyle cisimlerin şeklini tanımayı mümkün kılarak şekillerinden ve karşılıklı konumlarından ileri gelme tüm gerçek bilgileri elde etme" şeklinde belirtmiştir.

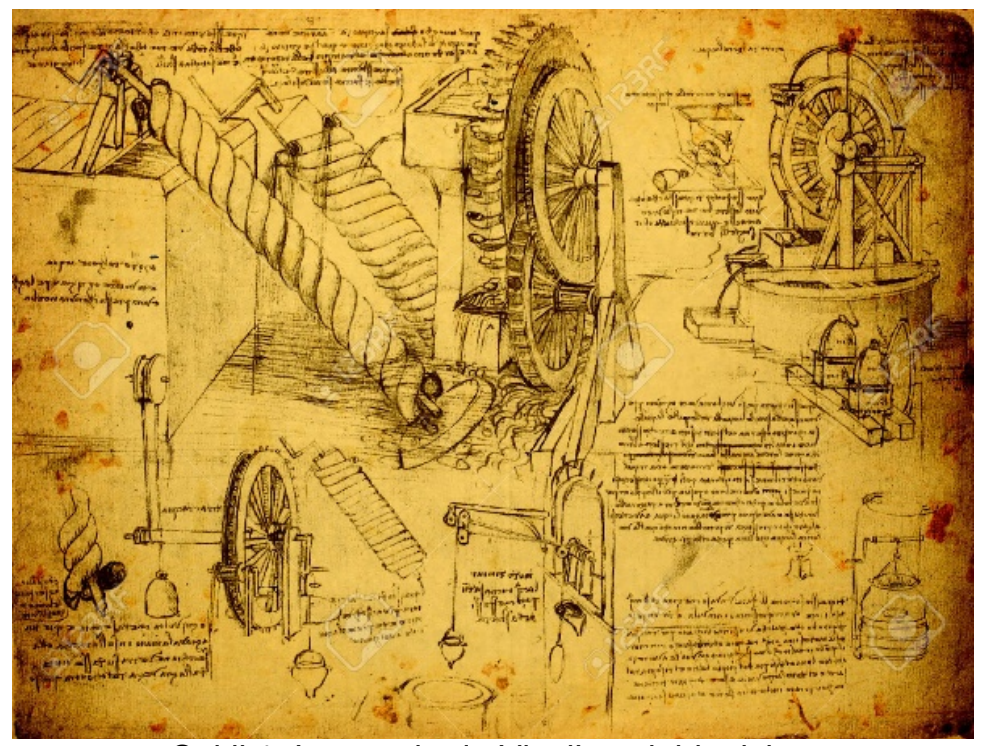

Şekil 1: Leonardo da Vinci'ye ait bir çizim.

Sanatçının eserleri teknik resmin ilk örneklerindendir. (URL3)

${ }^{4}$ URL2:http://users.metu.edu.tr/beyaz/304/sunumlar/FransizDevrimiDonemiveMatematik.pdf izlenme tarihi 06052016 
"Tasarı Geometri ve Teknik Resim" dersleriyle; uluslararası teknik resim kurallarına göre, cisimlerin iki boyutlu ve üç boyutlu görünüşleri, kesitleri detaylı bir şekilde çizilebilir ve objenin tam olarak gösterimi sağlanmış olur. Bunun yanı sıra bu ders, izdüşüm kavramı hakkında farkındalık sağlar. "Tasarı Geometri ve Teknik Resim" dersi; öğrencinin üç boyutlu düşünme, akıl yürütme, soyut düşünebilme gibi becerilerini geliştirir. Tasarı geometri, zihne esneklik kazandıran bir metottur ve çizim dünyasında, bilgisayar ortamında çizime geçilmesinden bir önceki devrimdir. Tasarımların artık bilgisayar ortamında yapılabilirliği bir devrim olarak yorumlansa da; çizim dünyasında, bilgisayar çağına değin geliştirilen tüm tekniklerin ve bilgilerin bilgisayar programlarına yazılımlarla aktarıldığı ayrıca, üç boyutlu düşünebilme ve bu düşünceyi farklı açılardan üç boyutlu olarak zihninde detaylandırabilme yeterliğini kazanmamış bir bireyin, bilgisayarda tasarım yapmayacağı da bilinmelidir. Bilgisayar programının sunduğu olanakların ve arşivinin içeriği ile sınırı kalınan durumlarda bireyin yaptığı tasarımdan söz etmek yerine çizim programının yaptığı tasarımdan bahsetmek daha doğru olacaktır.

Mimarlık, Planlama ve Tasarım Temel Alanı eğitiminin ilk yılında verilmesi gereken "Tasarı Geometri ve Teknik Resim" dersi; öğrencilerin çoğu tarafından algılanmakta zorlanılan derslerdendir. Bunun başlıca nedeni; mevcut lisans öncesi eğitim programına bu dersin alınmamış olmasıdır. Ülkemizde eğitim faaliyetlerine devam eden Sankt Georg Avusturya Lisesi gibi yabancı kaynaklı eğitim kurumlarının ve meslek liselerinin ders müfredatlarına seçmeli ders olarak tasarı-geometriyi dâhil ettikleri ve öğrencilerinin almayı hedefledikleri lisans eğitimlerini lisans öncesi eğitimde destekledikleri bilinmektedir. Oysaki yürürlükteki lisans eğitimi öncesindeki eğitim planında, geometrinin epür düzlemi ile ilişkilendirilerek anlatılmaması sebebi ile öğrencilerde gelişemeyen üç boyutlu düşünme becerisi, lisans eğitimine gelindiğinde büyük bir çoğunluğun zorlandığı, gerekliliğinin zorlanmadan dolayı anlaşılamadığı bir durumu ortaya çıkarmaktadır. Ders kapsamında anlatılanlar birçok öğrenciye çok soyut gelmekte ve dersin ileriye dönük meslekle bağlantısı kurulamadığı için, öneminin de yeterince farkına varılamamaktadır. Tasarı geometrinin öğrettikleri, çok somut bir bilgiye işaret eder. Örneğin; yapı inşaatı esnasında bir sıva ustasının işini yaparken her ne kadar farkında olmasa da- belirlediği noktalarla bir düzlem oluşturup sıvasını çekmesi geometrik bir çözümdür. Bir mimarın; yapının çatı çözümlemesi, çatının baca ile birleşim detayları, yapının herhangi bir noktasındaki bir elemanının nokta detayının çizimini yaparken ihtiyaç duyduğu üç boyutlu düşünce sisteminin temeli her zaman tasarı geometri dersinin öğrettikleri ile bağlantılıdır. Bu sebeple, tasarı geometri sayesinde tasarım doğru kurgulanabilmekte ve teknik resim kuralları sayesinde doğru ifade edilebilmektedir.

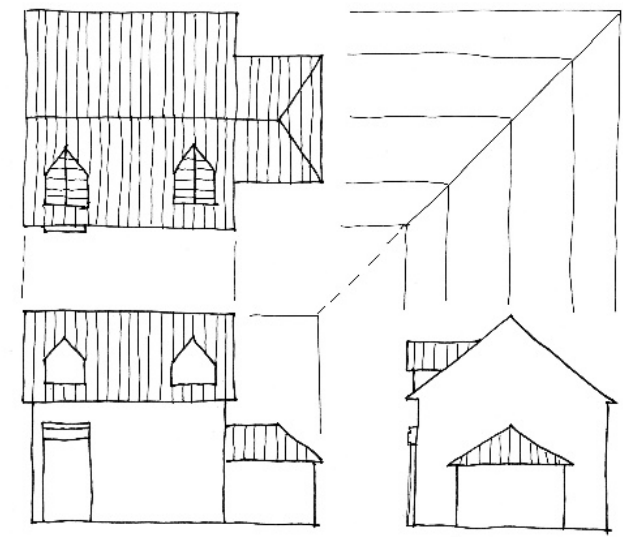

Şekil 2: Plan ve görünüşleri ile örnek çatı çizimi.

Yazıda bahsedildiği gibi tasarı geometriyi temel alan bir çizim örneği. (URL4) 


\section{PERSPEKTIF}

Yazının bulunmasından evvel, insanlık tarihinin gelişimini bizlere aktaran en belirgin uygarlık kalıntıları perspektif resimlerdir. Günümüzde insanlık tarihinin yeniden yazılmasına neden olacak Urfa Göbeklitepe (M.Ö.10000) buluntularındaki süslemelerdeki perspektif çalışmaları ve tasarlanmış mekânlardaki önceden kurgulanmış perspektifler izlenebilmektedir. Antik dönemlerde adı konmamış olsa bile, eski çağ resimlerinde dahi bir perspektif anlatım çabası gözlemlenmektedir. Tıpkı tasarı geometri gibi, perspektif de Rönesans ile birlikte gerçek geometrik kişiliğine kavuşmuştur. Perspektif ve resim üzerine ilk detaylı inceleme ise Leoan Batista Alberti'nin "De Pictura" adlı eserinde yer almaktadır.

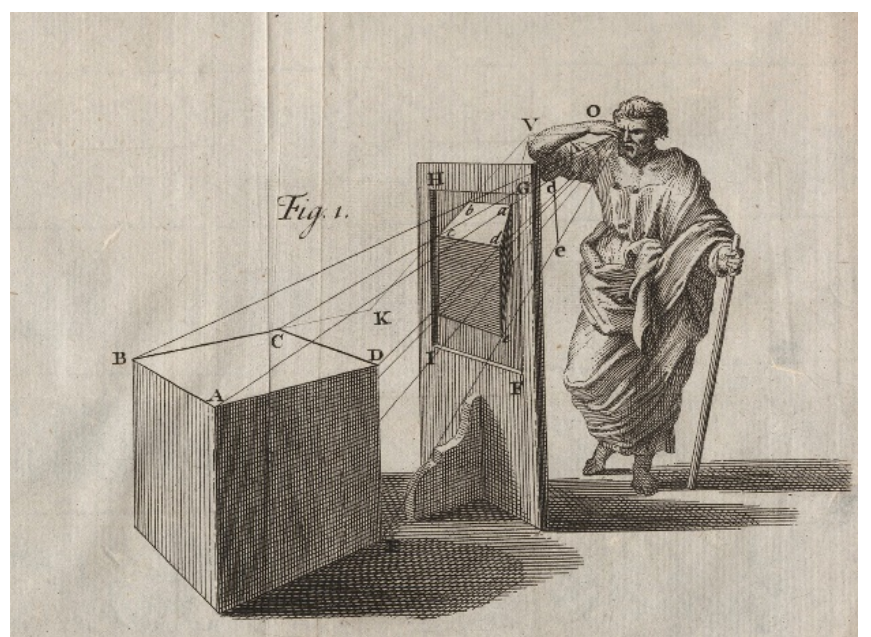

Şekil 3: Tarihte ilk kez perspektif üzerine inceleme yapmış ünlü İtalyan mimar Leon Batista Alberti'ye göre, bir resim dış dünyaya açılan bir pencere etkisi bırakmalıdır. (URL5)

Üç boyutlu hacimsel bir nesneyi, iki boyutlu bir düzlem üzerinde çeşitli çizgisel anlatım yolları ile resimleme yöntemine perspektif adı verilir. "Görüldüğü gibi resmetmek", perspektifin temelini oluşturur. Öyleyse denilebilir ki, perspektifte en önemli şey bakış açısıdır. Perspektif resimde derinlik, bakış açısına göre verilir. İnsan gözü şekil itibarıyla küresel yüzey üzerine görüntü alırken, düzlem yüzey üzerine çalışan perspektifte deformasyon kaçınılmazdır. Deformasyonu asgariye indirmenin tek yolu, bakış açısını küçültmektir. (MORÇÖL, 1979, s.n.y.)

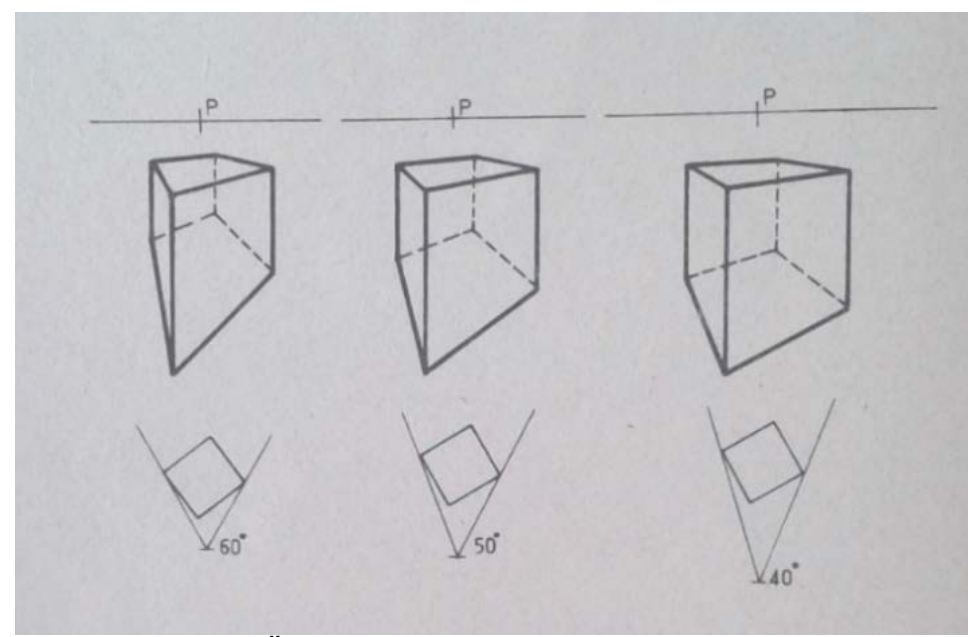

Şekil 4: Prof. Dr. Yılmaz MORÇÖL'e ait bir çizim. Aynı ufuk yüksekliğinden, bir küpün değişik bakış açılarının perspektif çizimleri. (Çizim: Mimar Tevfik İlter arşivi) 

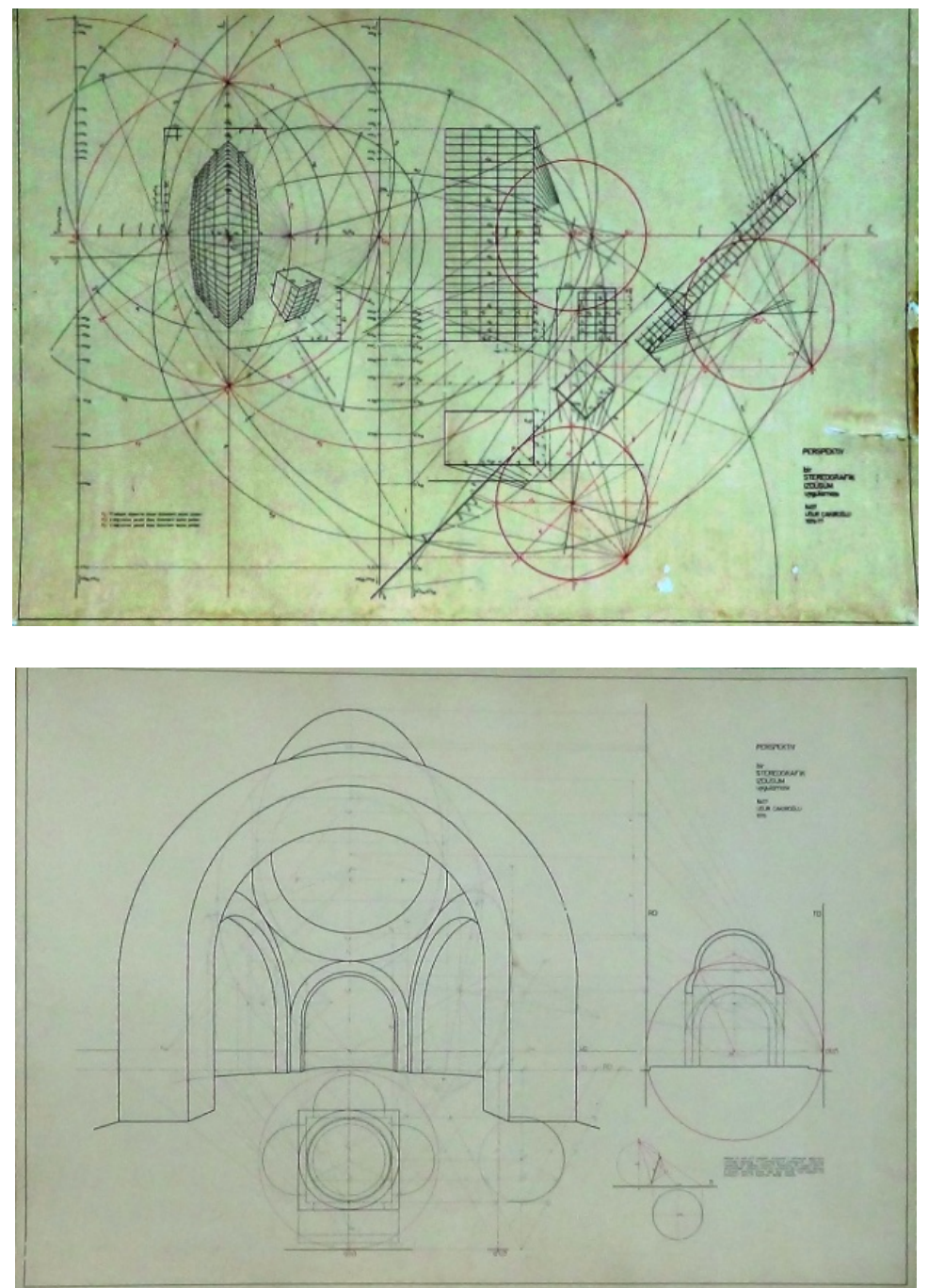

Şekil 5: Mimarlık eğitiminde tasarı geometri dersi için Prof. Dr. Yılmaz MORÇÖL'ün Öğr. Gör. Dr. Uğur Çakıroğlu'na yaptırdığı uygulama çizimlerinden örnekler, MSGSÜ, 1977. (Çizim:Mimar Uğur Çakıroğlu arşivi)

\section{PROF. DR. YILMAZ MORÇÖL'ÜN MESLEKI ÇALIŞMALARI}

Prof. Dr. Yılmaz MORÇÖL Hocamız; mezun olduğu 1961 yılından itibaren, mimar ve eğitimci olarak mesleğin projelendirme, uygulama ve eğitim aşamalarında yer almıştır. 1935 yılı Samsun doğumlu olup lisans, yüksek lisans ve sanatta yeterlilik eğitimini 1972 yılında Devlet Güzel Sanatlar Akademisi'nde tamamlayıp "Doçent" ünvanı almış, 1995 yılında Kocaeli Teknik Eğitim Fakültesi'nde "Profesör" olmuştur. 1998 yılında Kocaeli Üniversitesi Güzel Sanatlar Fakültesi İç Mimarlık Bölümü'nün kurucu bölüm başkanı olarak görev almıştır. Eğitim kariyeri boyunca Prof. Dr. Yılmaz MORÇÖL, özellikle "Tasarı Geometri ve Teknik Resim" ile "Perspektif" derslerinde eğitim vermiştir.

Bu derslerin Mimarlık, Planlama ve Tasarım Temel Alanı eğitimi için ne kadar önemli olduğu vurgulansa da, Prof. Dr. Yılmaz MORÇÖL yalnızca mimar veya tasarımcı adayları için değil, diş hekimliği bölümü öğrencileri için dahi bu dersleri anlattığı bilinmektedir. Yayınları da bu konular üzerine olup, 1971 yılı basımlı "Mimaride Gölge Üzerine" ve 1979 yılı basımlı "Perspektifte Deformasyon" dur. Anlattığı ders konuları ile ilgili yıllar boyunca biriktirdiği çoğu Almanca ve Rusça yayınlardan oluşan 
kütüphanesinin bir bölümü, son dönem beraber ders verdiği öğretim elemanlarının arşivlerinde korunmaktadır.
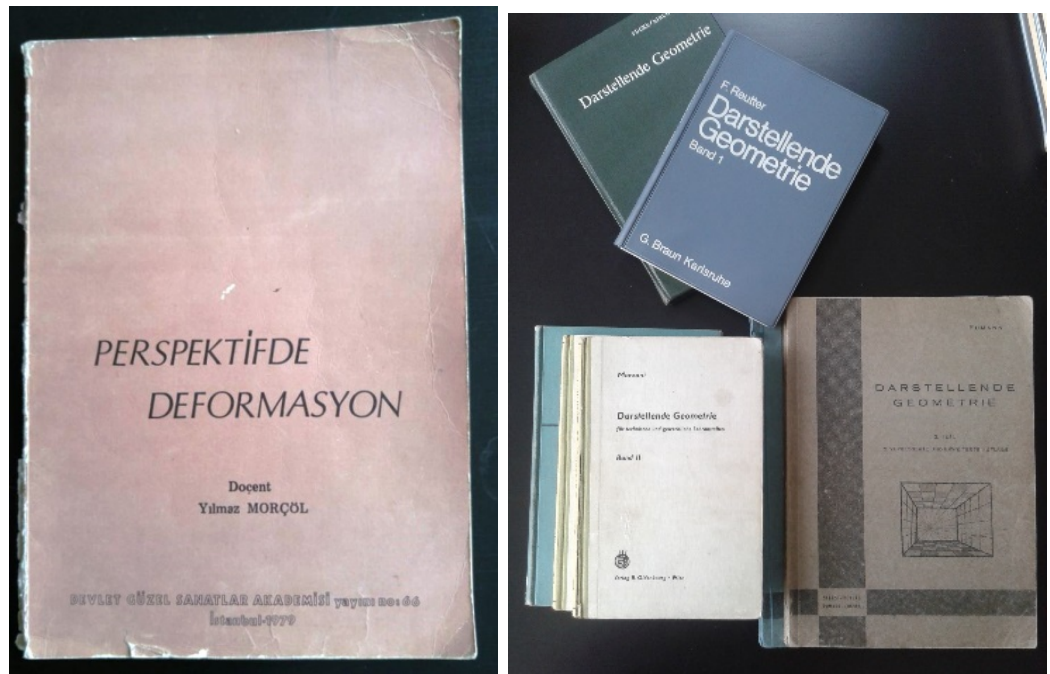

Şekil 6: Prof. Dr. Yılmaz MORÇÖL'ün yazdığı "Perspektifte Deformasyon" adlı kitabı ve ders notlarını hazırlarken kaynak kitap olarak kullandığı kitapların bir kısmı. (Fotoğraflar:Mimar Tevfik Ilter arşivi)
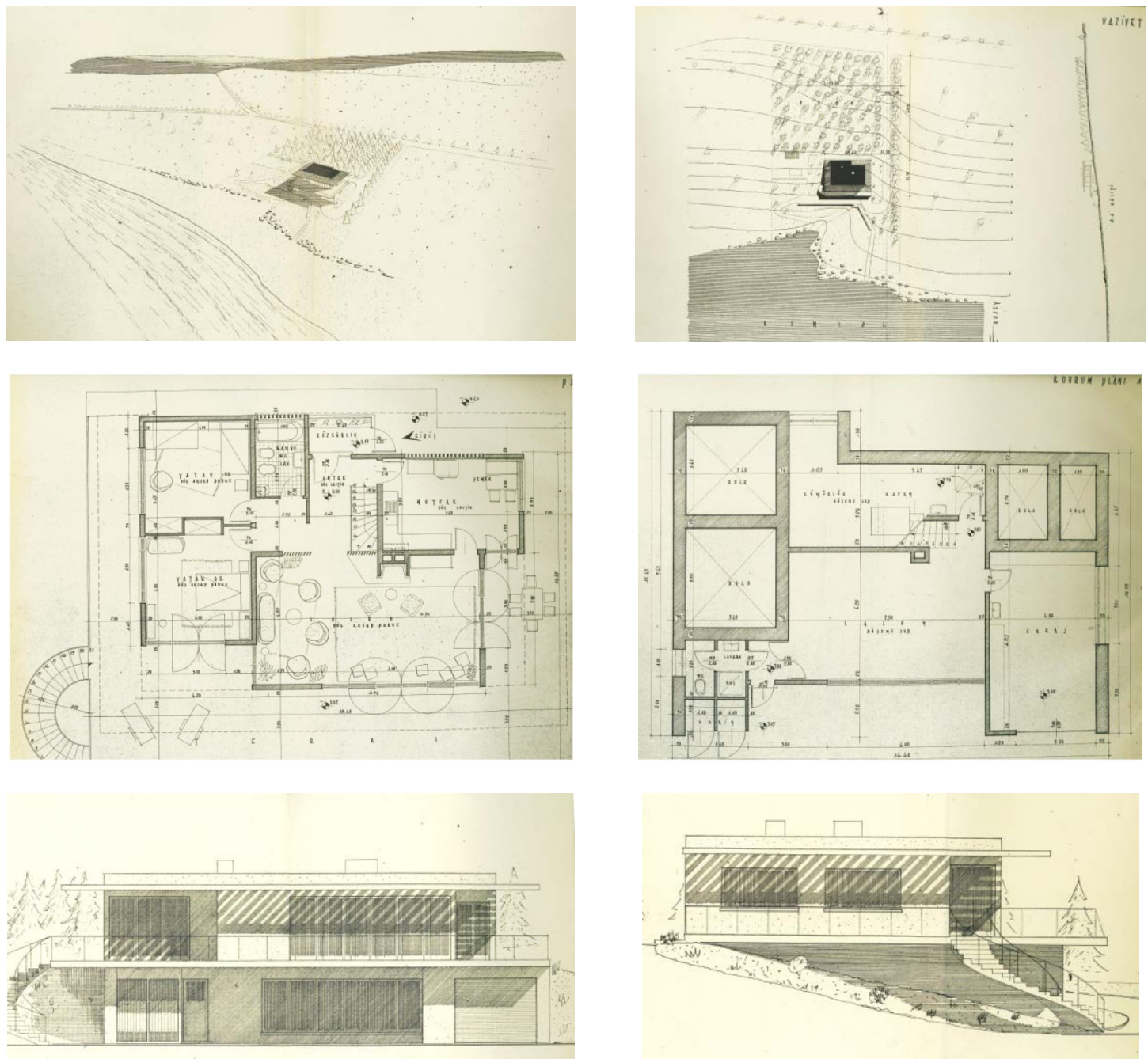

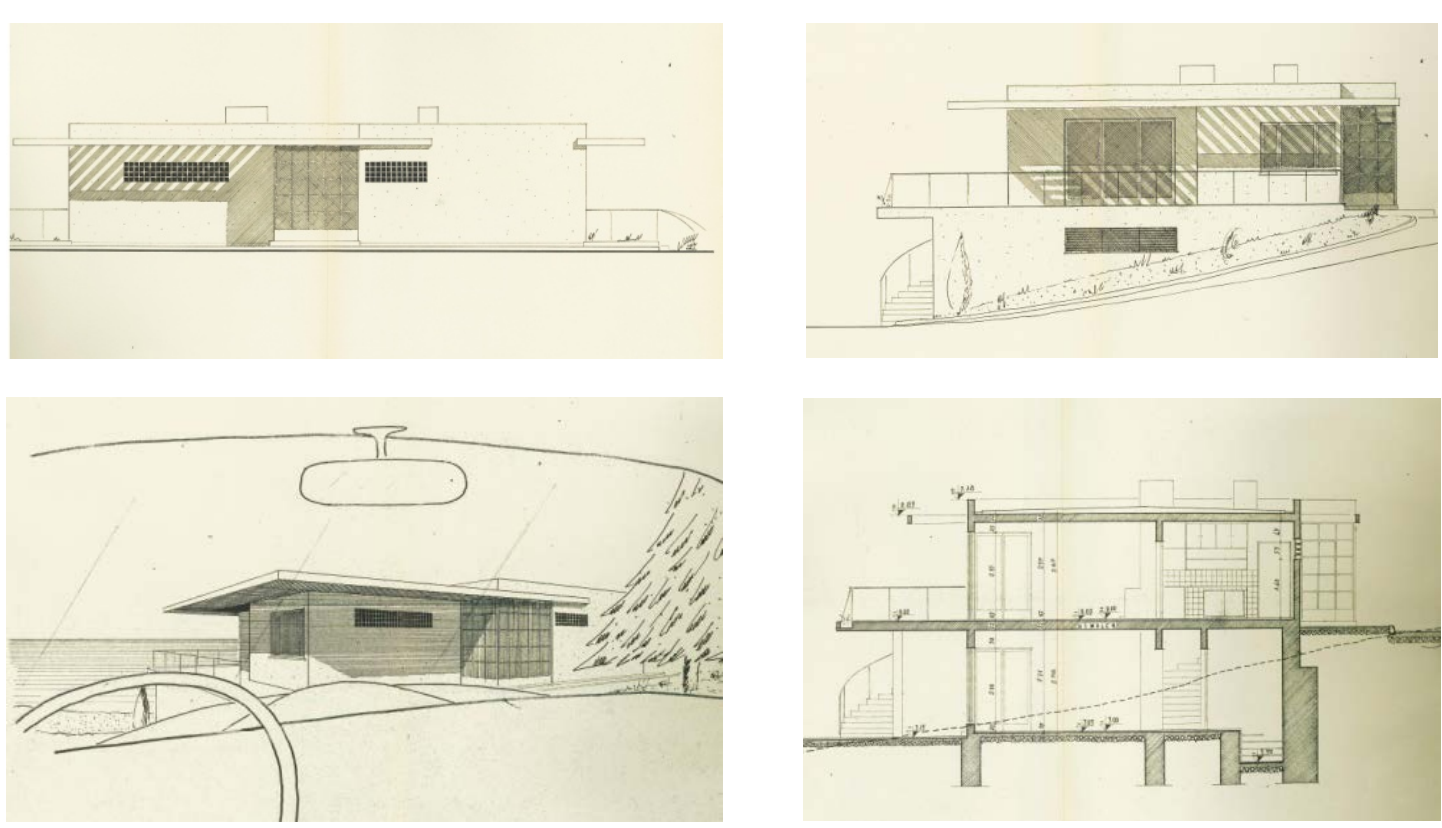

Şekil 7: Prof. Dr. Yılmaz MORÇÖL'ün, mimarlık eğitiminin ilk yılında Prof. Dr.Arif Hikmet Holtay'ın (1896-1968) Atölyesi'nde

teslimini Graphos kalemler ile çizdiği “Kilyos'ta Konut” projesinden görseller.

Her çizimi sade, düzenli ve disiplinli olan MORÇÖL'ün,

mimarlığın iletişim dili üzerinden çalışmaya devam edeceği anlaşılmaktadır.

(Çizimler: Yrd. Doç. Dr. Didem ERTEN BíLGiç arşivi)

Prof. Dr. Yılmaz MORÇÖL'e eğitim yaşamı boyunca derslerinde pek çok öğretim elemanı destek vermiştir. Kendisi ile birlikte uzun yıllar beraber çalışma şansı yakalamış iki öğretim elemanı Yüksek Mimar Tevfik İlter ve Dr.Uğur Çakıroğlu ile yapılan görüşmelerde Prof. Dr. Yılmaz MORÇÖL'ün tasarı geometri, teknik resim, perspektif, ışık, gölge gibi konuların tümüne hâkim olduğu aktarılmıştır. Derse asistanlarıyla birlikte girip öğrencilerin tümüyle şahsen ilgilenen ve adı gibi yılmadan bilgi aktaran bir kişiliğe sahip olduğu bilgisi vurgulanmıştır. Öğrencileri ile ilişkileri yalnızca okul içinde sınırı kalmayan öğrencileri için hem eğitici-öğretici, yol gösterici hem de yeri geldiğinde bir rol model görevi üstlendiği aktarılmıştır ve tanıyabildiğimiz kadarı ile iyi bir eğitimci olabilme, Prof. Dr. Yılmaz MORÇÖL'ün hayatının en önemli özelliği olmuştur. "Öğrencinin ortaya koyacağı başarı, hocanın kendisi kadardır." anlayışını benimsemiş ve hocalığı akademik bir kariyer olarak görmekten çok, her zaman daha iyisini öğretmeye ve kendisi de öğrenmeye çalışmıştır. Prof. Dr. Yılmaz MORÇÖL'ün dikkat çekici bir diğer özelliği de çok disiplinli ve dakik olmasıdır. Gençliğinde olduğu gibi, daha sonraları ilerleyen yaşına rağmen İstanbul Sarıyer'deki evinden Kocaeli Hereke kampüsündeki dersine hiçbir zaman gecikmemiştir.

\section{SONUÇ}

Tasarım yaparken ya da tasarlanan ürünü ortaya koyarken perspektif ile tasarı geometri ve teknik resim biliyor olmak, tasarlananın ortak bir dilde kâğıda aktarılıp görselleştirilebilmesine karşılık gelmektedir. Tasarı Geometri ve Teknik Resim dersleri öğrencinin üç boyutlu düşünme ve çözüm üretme yeteneğini geliştirmektedir. Yine benzer amaca hizmet eden Perspektif dersiyle edinilen bilgiler doğrultusunda; doğru bakış açısıyla çizilmiş, gerçeğe en yakın ve deformasyon ile hata oranının en az olduğu çizimler ortaya çıkarılmaktadır. Bu yüzdendir ki; "Tasarı Geometri ve Teknik Resim" ile "Perspektif" dersleri bu alan eğitiminin bel kemiğini oluşturur ve nitelikli bir eğitim 
sürecinde, adı geçen derslerin yeterli ders saatleri ile var olması eğitim kalitesi açısından önem arz etmektedir.

Yaşamının önemli bir bölümünü, adı geçen derslerin kuramlarını ve düşünme sistemlerini öğrencilerine aktarmak ile geçiren Prof. Dr. Yılmaz MORÇÖL bugünün binlerce meslek adamının hayatına dokunmuş bir kişidir. Sadece ders anlatımı ile değil, mesleğine ve öğrencilerine olan saygısı ve sevgisi ile de yetiştirdiği öğretim elemanlarına örnek olmuştur.

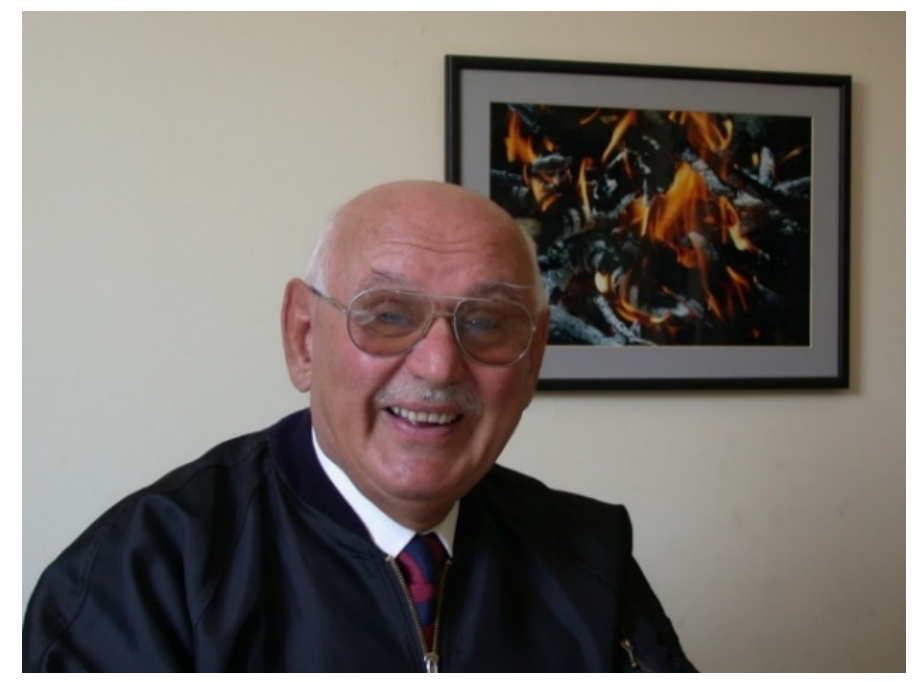

Şekil 8: Prof. Dr. Yılmaz MORÇÖL. ( 1935-2012 ) (Fotoğraf: Yrd. Doç. Dr. Didem ERTEN BíLGiç arşivi)

Kendisinin eğitimci kişiliği, mimar kişiliğinin önüne geçmiş gibi görünse de kendisini tanıyan hemen herkesin çok iyi bildiği "Yosma" ve "Metres" isimlerini taşıyan birbirinin aynısı iki teknenin tasarımını yapmış ve imalatı ile ilgilenerek 1976'da denize indirmiştir. Kamarasının üzerinden 15,75 metrelik birer ahşap direk taşıyan bu teknelerden "Metres", Prof. Dr. Yılmaz MORÇÖL tarafından uzun yıllar kullanılmıştır. 1997 yılında el değiştiren tekne, Atlantik okyanusunu geçerek Amerika'ya götürülmüştür.

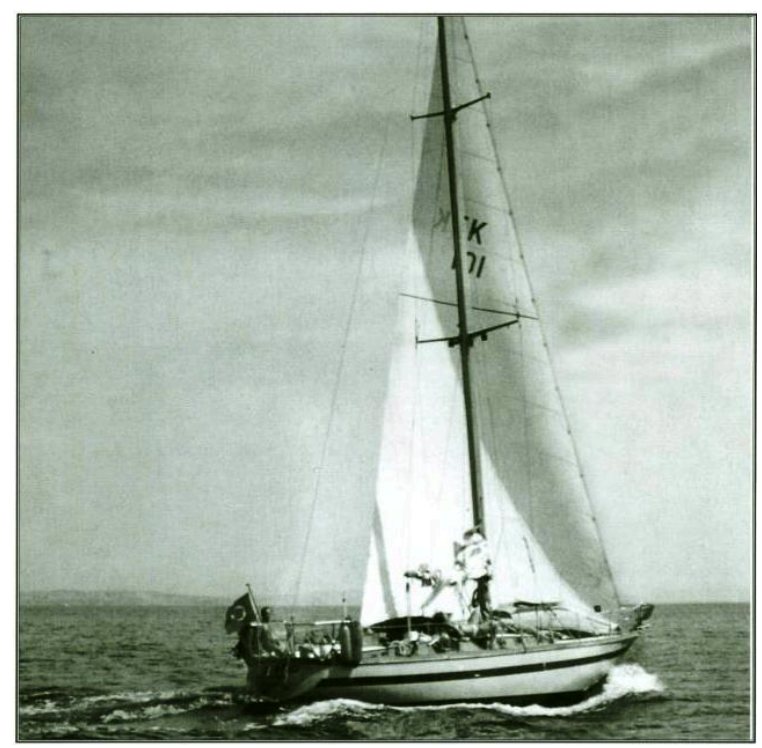

Şekil 9: Tasarımı ve uygulama sırasında kontrollü Prof. Dr. Yılmaz MORÇÖL'e ait tekne.

(Fotoğraf: Arkun Demircan Koleksiyonu) 
Prof. Dr. Yılmaz MORÇÖL, pek çok mimari proje yürütmüş ve birçok kurumda çalışmıştır. Listelemek gerekirse:

- 1956, Turizm Bankası Mimari Bürosu

- 1957, Çınar Oteli Mimari Bürosu / Yeşilköy

- 1958, Turisti Evler Mimari Bürosu / İstinye

- 1959, Dunlop Lastik Fabrikasi Bürosu / Adapazarı

- 1960-1963, BP Petrolleri A.Ş. Benzin İstasyonu Projeleri / İstanbul

- 1971-1972, Adapazarı ve Eskişehir Üniversiteleri'nde Tasarı Geometri ve Teknik Resim Hocalığı

- $\quad$ 1966, Devlet Güzel Sanatlar Akademisi Mimarlık Bölümü Asistanlığı

- 1966-1970, İnşaat müteahhitliği

- 1966-1972, Devlet Güzel Sanatlar Akademisi Giriş Sınavları Tanzim ve Yönetmeni

- 1983,7 adet ilkokul için şantiye müdürlüğü / Suudi Arabistan

- 1984, kendi evinin inşaatı / Marmaris

- 1985-1987, Nato Enf. Deniz Daire Başkanlığı Aksaz Deniz Üssü İnşaat Kontrol Amiri / Muğla

- 1987, Otel Lidya İlave Binası için inşaat şantiye müdürlüğü / Marmaris

- 1988, Maya Tatil Köyü için inşaat şantiye müdürlüğü / Marmaris

- 1989-1990, Müt. Entes Aksaz için inşaat şantiye müdürlüğü / Marmaris

- 1990-1991, Müşavir Tümaş Aksaz için inşaat şantiye müdürlüğü / Marmaris

- $\quad$ 1992, Coco Cola Fabrikası İnşaat Şantiye Müdürlüğü / Sapanca

- 1993, Müt Altek Toplu Konut 520 adet daire için inşaat şantiye müdürlüğü / Halkalı

- 1998, Kocaeli Üniversitesi, Güzel Sanatlar Fakültesi, İç Mimarlık Bölüm Başkanlığı.

Kendisini saygı,rahmet ve özlemle anıyoruz.

\section{KAYNAKÇA}

\section{BASILI KAYNAKLAR}

AKBIYIK, Aysun. "Türk Standartlarında ve Avrupa Standartlarında Teknik Resim Standartlarındaki Gelişmeler”, Pamukkale Üniversitesi / Fen Bilimleri Enstitüsü / Makine Eğitimi Anabilim Dalı Yüksek Lisans Tezi, 1998

ÇEVIK, Mehmet. "Teknik Resime Giriş”, Dokuz Eylül Üniversitesi / İnşaat Mühendisliği Bölümü Ders Notları, 2010

MORÇÖL, Yılmaz. "Perspektifte Deformasyon", İstanbul Devlet Güzel Sanatlar Akademisi / Yüksek Mimarlık Bölümü Doçentlik Tezi, 1972

ÖZDEMiR, Elvan Elif. "Mimarlık Eğitiminde Tasarım Sürecinin Geliştirilmesi Yönünde Bir Yöntem Arayışı", Gazi Üniversitesi / Fen Bilimleri Enstitüsü / Mimarlık Anabilim Dalı Doktora Tezi, 2013

YURTSEVER, Bengi. "Mimarlık Eğitiminde Eleştirel Düşünme Becerisinin Rolü: Birinci Yıl Tasarım Eğitimi”, İstanbul Teknik Üniversitesi / Fen Bilimleri Enstitüsü / Mimarlık Anabilim Dalı / Mimari Tasarım Programı Yüksek Lisans Tezi, 2011 
WEB KAYNAKLARI

URL1:http://www.yok.gov.tr/documents/10279/314121/A tablo8 300114.pdf/93603193 -5de3-4ff9-928e-245cc184b2b1, izlenme tarihi: 29112016

URL2:http://users.metu.edu.tr/beyaz/304/sunumlar/FransizDevrimiDonemiveMatematik .pdf izlenme tarihi 06052016

URL3: http://k32.kn3.net/taringa/2/C/7/0/6/F/caneloperez/285.jpg izlenme tarihi: 2911 2016

URL 4: https://drawinghand.files.wordpress.com/2012/11/multi-view-2.jpg) izlenme tarihi: 29112016

URL5: http://tombrockelman.com/2014/02/16/the-other-side-of-the-canvas-6/ izlenme tarihi: 29112016

FOTOĞRAF KAYNAKLARI

ILTER, Tevfik, Yüksek Mimar (YTU)

ÇAKIROĞLU, Uğur, MSGSÜ Mimarlık Fakültesi Öğretim Elemanı (Dr.)

DEMIRCAN, Arkun, Arkun Turizm Yat İşletmeciliği

ERTEN BİLGIÇ, Didem, Kocaeli Üniversitesi, Mimarlık ve Tasarım Fakültesi Öğretim Üyesi (Yrd. Doç. Dr.) 